\author{
Н. А. Николина \\ Московский педагогический государственный университет \\ (Россия, Москва) \\ admin@riash.ru
}

\title{
СТРУКТУРА И ФУНКЦИИ ДЕФИСНЫХ КОМПЛЕКСОВ В СОРЕМЕННОЙ ПИСЬМЕННОЙ РЕЧИ
}

В статье рассматриваются новые типы образований, оформленных посредством дефиса и получивших в последние десятилетия широкое распространение в современной письменной речи. Выделяются структурные типы дефисных комплексов, определяются их основные функции: номинативная, функция категоризации, функция оформления фразеологизованных конструкций и речевых стереотипов, оценочная функция, функция логического выделения. Отмечаются сферы использования дефисных комплексов: философский дискурс, современная художественная речь, литературно-критический дискурс, интернет-коммуникация. Показана связь рассматриваемых единиц с активными процессами в современном русском словообразовании, в частности с усилением в нем тенденции к компрессии. Дефисные комплексы рассматриваются как единицы, занимающие промежуточное положение между словами и синтаксическими конструкциями. Большинство из них сохраняет окказиональный характер, однако их интенсивное использование в речи свидетельствует об активизации в современном русском языке лексико-синтаксического словопроизводства, росте его деривационного потенциала. В связи с этим предлагается расширить представления о моделях сращения, функционирующих в современной русской речи. Дефисные комплексы соотносятся со сходными по структуре объединениями, в которых используются другие знаки или наблюдается слитное написание компонентов. Отмечаются факторы, влияющие на распространение в речи дефисных комплексов.

Ключевые слова: дефис, голофразис; компрессия, раздельнооформленность; сращение; словопроизводство; цельнооформленность, функции.

В конце XX в. заметно активизировались деривационные процессы, связанные со свертыванием различных синтаксических конструкций. С одной стороны, высокую продуктивность проявляет универбация, предполагающая замену субстантивных словосочетаний однословным суффиксальным образованием (выделенка, 
смешанка, научник и др.), с другой стороны, интенсивно используются различные типы сложных дериватов.

В последние десятилетия XX в. в русской письменной речи получили широкое распространение оформленные посредством дефиса комплексы, представляющие собой объединение компонентов словосочетания или предложения. Так оформляются недискретные, с точки зрения автора, высказывания, сочетания, воспринимаемые им как одна целостная номинация. Такие дефисные комплексы все чаще встречаются в философских текстах и в современной художественной речи, реже в языке СМИ; ср., например:

Это чистота потерянного рая, чистота мира-вне-сегодня (А. Ляхович);

Аврора... на месяц заперлась в гостинице-с-кондиционером (А. Иванов);

Но главное - это сессии, недельное удаление-от-мира (А. Матушинский);

Не-знаю-где-град (Д. Бобышев);

Бытие-в-мире - способ осуществления человеческого существа как... бытиявот (В. Бибихин).

Активизация таких построений в русской письменной речи во многом обусловлена влиянием сходных по структуре единиц, которые регулярно используются в других языках и все чаще воспроизводятся в переводах. Для философского же дискурса это характерные для него в ХХ в. приемы терминообразования, ставшие, например, приметой стиля М. Хайдеггера и его последователей. Однако, как отмечал Вяч. Иванов, тенденция образования дефисных комплексов «кажется принадлежащей не одному автору и языку, а эпохе...» [Иванов 2004: 45].

Рассматриваемые дефисные комплексы в русской письменной речи явление не новое. Так, в поэтических текстах М. Цветаевой 20-30-х гг. встречается 336 таких единиц [Нарынская 2004]: врозь-состояние, любовь-вблизи, навек-человек и др. Используются они и в русских философских сочинениях 30-х гг. ХХ в. Например: Самое ее бытие есть непосредственное бытие-для-себя, самопрозрачность (С. Франк).

Однако активизация дефисных комплексов в различных жанрах письменной речи происходит именно в конце XX в. При этом она поддерживается сходными процессами в современной интернет-коммуникации и, как уже отмечалось, воздействием усилившегося межъязыкового взаимовлияния.

Регулярное обращение к дефисным комплексам в современной письменной речи отражает общую тенденцию к компрессии, характерную для развития языка, и мотивировано стремлением, во-первых, найти новые способы оформления фразеологизованных сочетаний и различных прецедентных феноменов, во-вторых, актуализировать связи, существующие между компонентами высказывания. Ср., например:

довольно глупо раскатать губу-

не-дуру-и попасть эпохе в плен

(В. Куллэ)

Что сказавиий-в-сердиее-своем

Еще мог сказать! (И. Булатовский).

В старые времена весь-я-не-умру было делом выбора (М. Степанова). 
Содержащие дефис единицы соотносятся с разными синтаксическими структурами, компоненты которых подвергаются объединению, соответственно, используются разные модели их построения. В один дефисный комплекс могут объединяться компоненты:

1) простого подчинительного словосочетания: прыжок-в-уме (И. Булатовский), будущее-после-эксперимента (О. Брейнингер); общага-на-крови (А. Иванов);

2) сложного словосочетания: размышления-на-заданную-тему (Л. Иоффе); душ бывает черныци-на-них-осадок (А. Поляков);

3) предложение или его предикативная часть: Музыка отлучилась в я-не-скажукуда (В. Куллэ); Она перестала быть Олей Белкиной. Теперь она... Оля-nanaкоторой-убил-голубя (Е. Михалкова).

Начало объединения слов, входящих в исходную синтаксическую структуру, маркируется дефисом как «компромиссным знаком» (В. М. Павлов), который, как это ни парадоксально, одновременно служит знаком незавершенности этого процесса. В процессе порождения новой единицы раздельнооформленность производящей синтаксической структуры сменяется относительной цельнооформленностью комплекса. В аспекте словообразования такие построения могут рассматриваться как особая разновидность сращений. Сращение традиционно рассматривается как слияние компонентов подчинительного словосочетания, однако в широком смысле оно может определяться и как такой способ словообразования, в основе которого слияние компонентов не только словосочетания, но и предложения. В этом случае как сращения особого типа могут интерпретироваться и голофрастические образования.

Распространение дефисных комплексов в современной письменной речи, таким образом, свидетельствует об активизации лексико-синтаксического словопроизводства, о его возрастающем деривационном потенциале в русском языке.

Дефисные комплексы, в основе которых объединение компонентов подчинительных словосочетаний или предложений, взаимодействуют в современной речи с дефисными комплексами, в основе которых бессоюзный сочинительный ряд. Например: ...Он... читал запоем, подряд всех-всех, Манна-Белля-Тургенева-Толстого-Добычина... (М. Кучерская); ...ОТ макарон-каш-картошки худеют (О. Новикова). Такие объединения возникли в русской речи значительно раньше.

Если дефисные комплексы, основанные на слиянии компонентов подчинительного словосочетания или голофразисе, можно рассматривать как сращения или их аналог, то комплексы с сочинительными отношениями компонентов пополняют состав единиц, образованных сложением, которое характеризуется высокой степенью продуктивности в современном словопроизводстве.

В состав дефисного комплекса могут входить три-четыре компонента. Например: снег-по-лоб (А. Афанасьева), следь-от-глаз (Е. Поспелов), заезжий-на-часездок (Е. Клюев); почти-что-лето (Е. Михалкова).

Голофрастические образования включают и большее число компонентов:

Ребенок сыл-обут-одет-крышиа-над-головой... (А. Иванов) 
Давай играть:

в войну,

в не-наступишь-на-ногу-умрет-мама

а падающего толкни (А. Горбунова).

Однако чем больше компонентов входит в исходное сочетание, тем реже оно трансформируется в цельнооформленную дефисосодержащую единицу.

Дефисные комплексы выполняют в современной письменной речи ряд функций.

Во-первых, они используются для оформления устойчивых, регулярно воспроизводимых отрезков речи: точных и модифицированных цитат, речевых стереотипов, клише. Таким образом, они служат «новым способом фразеологизации речевого сегмента» [Зубова 2000: 304]. Например:

И чуден-этот-Днепр (Н. Искренко);

Я то и дело ловлю себя на этом слове, будто речь идет о книге про любит-нелюбит (М. Степанова);

И на земле взойдут

под накат сапогов

глухой мир, немой труд,

май-нашли-дураков (И. Булатовский);

В молодости всяк хочет жить, чтоб мыслить-и-страдать (Ю. Малецкий).

В интернет-коммуникации дефисные комплексы служат также способом передачи чужой речи, эта функция последнее время реализуется и в современной художественной речи. Передача чужой речи, как правило, представляет собой «цитирование прямой речи как типичной реакции на предмет/явление либо как ярко иллюстрирующей событие/явление» [Занегина 2012: 696]. Ср., например:

Сначала друзья умещаются в автоответчике:

Всё-что-хотите-говорите-после гудка.

(О. Хлебников).

Во-вторых, рассматриваемые дефисные комплексы выступают в собственно номинативной функции и заполняют лакуны, существующие в лексическом составе языка. В результате возникают новые цельнооформленные номинации, подчеркивающие тесную связь составляющих их компонентов. Номинативная функция реализуется, например, в терминообразовании в сфере философского и искусствоведческого дискурса: бытие-в-мире, драма-для-чтения, пьеса-не-для-театра, текст-в-тексте, образ-в-движении и др.

Номинативная функция взаимодействует с функцией категоризации: использование рассматриваемых построений предполагает обычно «выделение особого класса предметов» [Занегина 2012: 696] или лиц. Например: Идиллическая цельность персонажа представляет собой нераздельность я-для-себя от я-для-других (Н. Тамарченко, В. Тюпа). Зоя станет «женщиной-под-воздействием» (А. Иванов).

B-третьих, дефисные комплексы могут выступать в речи в оценочной функции, чаще всего они выражают негативную или ироническую оценку: Театр-наПомойке (В. Аксенов), романчик все-равно-с-кем (М. Кучерская), мама-с-обложки (Е. Михалкова). 
Рассматриваемые дефисосодержащие единицы выполняют и ряд частных функций. Так, применительно к интернет-коммуникации Н.Н. Занегина отмечает такие функции, как «логическое выделение» и «подчеркивание связи зависимых слов именно с данным главным словом» [Занегина 2012: 696].

В художественной речи функции дефисных комплексов заметно усложняются: они, отражая интенции автора, воспроизводят целостный фрагмент индивидуально-авторской картины мира, служат средством создания художественного образа, «подчеркивают фонетические и семантические связи сочетающихся ... слов» [Николина 2009: 131], определяют ритмический рисунок текста, делают относительным «само представление о структурной оформленности слова и невозможности... пауз внутри него» [Фатеева 2004: 55].

Я в Библии-воды поймаю рыбу (А. Поляков);

осторожно присутствие в памяти

идеи-колес-вдоль-кустарников-выжженных

вкривь выявляет виски... (Г. Айги);

светом

страдающе-в-облике-собранным

из первосвета явившись

вздрагивая

ждать (Г. Айги);

Мы пьем из-смерть-с-пути-метафор (В. Мельников).

Сами все научились

Изменяться, как нравится,

В мастерские-спускаясь-подземелья.

(М. Степанова).

Шел снег и быстрые следы-от-глаз скрывал

(Е. Поспелов).

Регулярное употребление дефисных комплексов в поэтических текстах характерно для определенных индивидуальных стилей, например таких поэтов, как Г. Айги, Н. Азарова, Т. Грауз, Е. Поспелов, М. Степанова.

В философских текстах рассматриваемые типы дефисных образований служат терминами или выступают как эквивалентное средство перевода имеющих сходную структуру единиц. Так, базовые понятия философской системы М. Хайдеггера последовательно передаются в русских переводах дефисосодержащими построениями: бытие-в-мире, бытие-к-смерти, бытие-между, воля-к-смерти, самопродвижение-к-успеху, умение-быть-в-мире и др.

Рассматриваемые дефисные комплексы в современной речи соотносятся с многочисленными образованиями, в которых объединяемые компоненты оформляются как слитные написания либо между ними используется косая черта как условный пограничный сигнал. «Такие склеенные образования являются новым средством категоризации действительности - они не только придают тексту... выразительность, но и подчеркивают определенный смысл, который обычно передается несколькими словами» [Шмелева 2015: 49]. 
Дефисные комплексы, широко распространенные в современной речи, занимают промежуточное место между синтаксическими конструкциями и лексическими единицами. Бо́льшая их часть сохраняет окказиональный характер. Однако активность их образования и употребления свидетельствует об усилении продуктивности таких способов словообразования, как сложение и сращение, и «возрастающей свободе словосложения» [Павлов 1985: 122]. Представляется, что в настоящее время сращение вряд ли целесообразно ограничивать только двумя моделями, которые отмечаются в «Русской грамматике» 1980 г.: «наречие + прилагательное или причастие», «имя существительное + прилагательное или причастие». В рамках этого способа появляются новые модели, что обнаруживает новые тенденции его развития.

\section{Литература}

Занегина Н. Н. Словосочетания-записанные-через-дефис как способ категоризации и новый прием языковой выразительности в русском языке // Компьютерная лингвистика и интеллектуальные технологии: По материалам ежегодной международной конференции «Диалог» (2012). Вып. 11. М., 2012. Т.1. С. 696-705 с.

Зубова Л. В. Современная русская поэзия в контексте истории языка. М.: Новое литературное обозрение, 2000. 432 с.

Иванов Вяч. В. Лингвистика третьего тысячелетия. Вопросы к будущему. М.: Языки славянской культуры, 2004. 208 с.

Нарынская Н. Ю. Структурно-семантические особенности лексико-синтаксических окказионализмов в идиолекте М.И.Цветаевой: автореф. дис. ...канд.филол. наук. Ростов-на-Дону, 2004. 22 с.

Николина Н. А. Активные процессы в языке современной русской художественной литературы. М. : ИТДГК «Гнозис», 2009. 336 с.

Павлов В. М. Понятие лексемы и проблемы отношений синтаксиса и словообразования. Л. : Наука, 1985. 299 с.

Фатеева Н.А. Поэзия рубежа XX-XXI веков: что происходит в языке и с языком // Russica Romana, vol. XI — Pisa; Roma, 2004. C. 53-64.

Шмелева Е.Я. Интернет-коммуникация: новые тенденции в русском словообразовании // Верхневолжский филологический вестник. 2015. №2. С. 46-52. 


\author{
N. A. Nikolina \\ Moscow Pedagogical State University \\ (Russia, Moscow) \\ admin@riash.ru
}

\title{
THE STRUCTURE AND FUNCTIONS OF HYPHENATED COMPLEXES IN MODERN WRITTEN LANGUAGE
}

The author considers new types of hyphenated complexes that got broadcast in the modern written language last decades. The author pointed out structural types of hyphenated complexes, names their main functions: nominative functions, categorization function, function of phraseologized constructions and speech stereotypes figuration, evaluation function, logical accentation function. There are spheres of hyphenated complexes use such as philosophical discourse, modern literary language, literature and critical discourse, Internet communication. The article shows the link of analyzing units with the active processes of the modern Russian word-formation especially with the gain of tendency to compression. Hyphenated complexes are intermediate in words and syntax constructions. The majority of them retains the occasional character but their overdraft proves the activation of lexical and syntax word-building, increasing of their derivational facilities. That side the author offers to extend the idea of fusion models functioning in the modern Russian language. Hyphenated complexes relate to structurally similar units that use other signs or joinedup writing. The author names the factors that influence on the spread of hyphenated complexes.

Keywords: hyphen, holophrasis, compression, separability, fusion, word-formation, continuity, function.

\section{References}

Zanegina N. N. [Word combinations written with a hyphen as the way of categorization and the new example of language emphasis] Komp'yuternaya lingvistika i intellektual'nye tekhnologii: Po materialam ezhegodnoj mezhdunarodnoj konferencii «Dialog» (2012). Issue. 11, Moscow, 2012, vol.1. Pp. 696-705. (In Russ.)

Zubova L.V. Sovremennaya russkaya poehziya $v$ kontekste istorii yazyka [The modern Russian poetry in the case of language history]. Moscow, Novoe literaturnoe obozrenie, 2000. 432 p.

Ivanov V. V. Lingvistika tret'ego tysyacheletiya. Voprosy $k$ budushchemu [Linguistics of the third millenium. Questions for the future]. Moscow: Yazyki slavyanskoj kul'tury Publ., 2004. 208 p.

Narynskaya N.Yu. Strukturno-semanticheskie osobennosti leksiko-sintaksicheskih okkazionalizmov v idiolekte M.I.Cvetaevoi. Avtoref. diss. kand. filol. nauk [Structuralsemantic special aspects of lexical-syntactic occasional words in idiolect of M.I. Cvetaeva]. Rostov-na-Donu, 2004. 22 p. 
Nikolina N.A. Aktivnye processy v yazyke sovremennoj russkoj hudozhestvennoj literatury [Active processes in the language of the modern fiction literature]. Moscow, ITDGK Gnozis Publ., 2009. 336 p.

Pavlov V. M. Ponyatie leksemy i problemy otnoshenij sintaksisa i slovoobrazovaniya [The concept of lexical unit and problems of syntax and word-formation relation]. Leningrad, Nauka Publ., 1985. 299 p.

Fateeva N. A. [Poetry of the turn of $20^{\text {th }}-21^{\text {st }}$ century: what happens in the language and with the language]. Russica Romana, vol. XI - Pisa; Roma, 2004, p. 53-64. (In Russ.)

Shmeleva E. Ya. [Internet-communication: new tendencies in Russian wordformation]. Verhnevolzhskij filologicheskij vestnik, 2015, No. 2, pp. 46-52. (In Russ.) 